\title{
EXPOSURE TO PESTICIDES AND CHILDHOOD CANCER RISK: HAS THERE BEEN ANY PROGRESS IN EPIDEMIOLOGICAL STUDIES?
}

\author{
JOANNA JUREWICZ and WOJCIECH HANKE \\ Department of Environmental Epdemiology \\ Nofer Institute of Occupational Medicine \\ Łódź, Poland
}

\begin{abstract}
Objectives: In Europe and the United States, cancer is a major cause of death among children aged 5-14 years. The role of environmental exposure to pesticides in carcinogenesis, although strongly postulated, is still unknown. Pesticides have been used since the early days of modern agriculture. They are biologically active compounds, which may pose health risk during or after their use. Materials and Methods: Epidemiological studies focused on childhood cancer and exposure to pesticides, conducted over the last seven years, were identified through searching PUBMED, MEDLINE and EBSCO literature bases. From each study, the following information was abstracted: type of cancer, type of exposure, study design, risk estimate, and study population. This review will try to answer the question on whether any further progress in epidemiology of childhood cancer due to pesticide exposure has been made. Results: Leukemia, brain cancer, non-Hodgkin's lymphoma and neuroblastoma are mentioned as potentially associated with pesticide exposure among children. Despite an increasing evidence in support of this finding, it is still limited because of the weakness of research methodology. The substantial weak points of numerous epidemiological studies of pesticide-related health effects are problems faced in exposure assessment, small numbers of exposed subjects, a limited number of studies focused on the majority of cancers, and difficulties in estimating critical windows of exposure. Conclusion: In the light of existing, although still limited evidence of adverse effects of pesticide exposure, it is necessary to reduce exposure to pesticides. The literature review suggests a great need to increase awareness among people occupationally or environmentally exposed to pesticides about their potential negative influence on health of their children.
\end{abstract}

Key words:

Childhood cancer, Agricultural work, Exposure to pesticides

\section{INTRODUCTION}

Pesticides form a large group of heterogeneous chemicals, which are used to kill insects, weed, fungi and rodents. Several classes of compounds are used for this purpose. On the one hand these substances bring a significant public health benefit by increasing productivity in the food industry and decreasing the incidence of diseases, on the other they raise public concern about potential effects of pesticide exposure on the development of fetus and child. There are multiple sources and routes of children's exposure to pesticides, which differ from those observed in adults. Children can be exposed to pesticides through a wide range of means, including carpets, house dust, chemically treated lawns, gardens and pets treated with parasite control products (carbamate, pyretroid or organophosphate insecticides). Young children who are likely to spend a large proportion of time on the floor or ground and who frequently put objects in their mouths could also be exposed via this route.

Pesticides may enter the body by dermal absorption, inhalation or oral absorption. Physiologic characteristics of young children, such as high intake of food, water and air per unit of body weight, may increase the level of received

Received: June 6, 2006. Accepted: August 31, 2006.

Address reprint requests to J. Jurewicz, Department of Environmental Epidemiology, Nofer Institute of Occupational Medicine, św. Teresy 8, 91-348 Łódź, Poland (e-mail: joannaj@imp.lodz.pl). 
dose. In children, the surface to volume ratio is higher than in adults, which results in a larger proportion of skin surface across which absorption can occur [1]. Breastfed infants may also ingest pesticides or pesticide metabolites present in the breast milk [2]. Because infants and small children are growing rapidly, they have greater energy demands than adults, which results in greater caloric and oxygen requirements. Infants drink more water, eat more food and breathe more air relative to body weight compared with adults, so they receive a higher dose when exposed to substances present in the air, water, soil and food [3].

Assessment of exposure to pesticides is a challenging process. Epidemiologists commonly use in their studies such exposure methods as survey [4], combinations of survey with visual observation [5], biological monitoring of pesticide metabolites in urine [6], ambient air monitoring, blood serum analysis or evaluation of dermal exposure intake [7]. Less common are measurements in breast milk and umbilical cord blood [2].

\section{Exposure to pesticides and the risk of childhood cancer}

Despite recent advances in the treatment of childhood cancers, such as Wilms' tumor and leukemia, pesticide exposure is still a leading cause of death among children aged 5-14 years in Europe as well as in the United States [8,9]. The role of environmental hazards has been postulated, but only in few cases (ionizing radiation, chemotherapeutic agents and dithylsilbestrol, a drug taken during pregnancy can cause vaginal adenocarcinoma in daughters) the scientific evidence is supportive [10]. The role of environmental exposure to pesticides in carcinogenesis is still unknown. The review of epidemiological studies suggests that children may be more susceptible to carcinogenic effects of pesticides than similarly exposed adults. However, the timing of exposure, duration, dose and susceptibility of parents, fetus and child play an important role in the observed outcome.

Exposures to specific mutagens could be etiologically important preconceptionally (through creation of germline mutations that could potentially be passed on the child), during pregnancy (through transplacental crossover), and postnatally (through direct transmission of exposure residues) [11]. Possible interactions between environmental carcinogens and genetic susceptibility have also been suggested [10].

In the late 1970s, several case reports on cancer among children exposed to pesticides were published. Pre- and postnatal exposure to termiticide chlordane was associated with neuroblastoama [12]. Cases of organophosphate insecticide exposure were linked to aplastic anemia and acute leukemia in children [13]. A recent case report has described congenital leukemia in a child after intensive use of permethrin (as a result of mother arachnophobia) at home [14].

Zahm and Ward [15] presented a detailed analysis of the available epidemiological data for or against association between pesticides and childhood cancer. Leukemia, brain cancer, non-Hodgkin's lymphoma, soft-tissue sarcoma and Hodgkin's disease were mentioned as potentially associated with pesticide exposure among children. However, several basic limitations of such investigations have been identified: exposure to pesticides based only on job title or self-reported pesticide use, non-specific pesticides exposure information, small numbers of exposed subjects, potential for recall bias, small number of studies focused on specific cancers, not taking account of possible genetic and environmental interactions. Most of the studies reviewed by Zahm and Ward [15] in 1998 comprised subjects exposed preconceptionally, thus offering little chance of identifying when pesticides might have exerted their effect and initiated the cancer under investigation. Only some childhood cancer studies have evaluated pesticide exposure during critical time periods, such as preconception (e.g., ever, 1 month or 6 months prior to conception), pregnancy (e.g., ever, the first trimester, the second trimester, the last trimester) and postnatal, including infancy, and the specified number of years preceding the diagnosis.

This review will try to answer the question on whether any further progress has been made in epidemiology of childhood cancer induced by exposure to pesticides and in particular to find out whether any limitations mentioned in the review by Zahm and Ward [15] have been overcome. 


\section{MATERIALS AND METHODS}

Epidemiological studies focused on childhood cancer and exposure to pesticides, conducted over the last seven years (1998-2005), were identified through searching PUBMED, MEDLINE and EBSCO literature bases. Key words used were: childhood cancer, agricultural work and exposure to pesticides. Language of publication criteria was not specified. From each study the following information was abstracted: type of cancer, type of exposure (environmental, occupational, household use of pesticides, specific chemicals), study design, risk estimate, and study population (number of cases and controls).

\section{RESULTS}

\section{Nervous system cancers}

Review conducted by Zahm and Ward [15] on the role of pesticides in the development of childhood brain cancer covered one case report, 16 case-control studies and one cohort study. Significant elevations in the risk of brain cancer and pesticide exposure were observed in nine studies. Insignificant elevations were observed in additional five studies and in three other studies no association between pesticide exposure and childhood cancer was found. Two studies examined the use of specific pesticides and the risk of childhood nervous system cancer. Chadduck et al. [16] noticed that the use of heptachlor during pregnancy was associated with gliosarcoma diagnosed in an infant 7 weeks of age. Davis et al. [17] found that exposure to carbaryl and diazinon was associated with childhood brain cancer.

The role of pesticides in the development of childhood brain cancer has recently been examined in Sweden $[18,19]$, the United States and Canada [20-23] as well as in the study conducted in seven countries including: the United States (San Francisco, Los Angeles, Seattle), Israel, Italy (Milan), Spain (Valencia), Australia (Sydney), France (Paris) and Canada (Winnipeg) [24] (Table 1). Almost all the studies evaluated the risk associated with parental occupational exposure to pesticides. The importance of paternal exposure was found in 4 studies $[18,19,20,22]$ and maternal in 2 studies [20,24].
An increased risk of nervous system tumors was demonstrated among children whose father was exposed to pesticides before conception; provided estimates of relative risk $(\mathrm{RR})=2.495 \%$ CI:1.3-4.4) [18]. Another study based on parental occupational exposure to pesticides found that among children of Swedish male pesticide applicators, tumors of the nervous system were most common, amounting to $39 \%$ of all cases of cancer in the cohort; standardized incidence ratio (SIR) $=1.01,95 \%$ CI:0.62-1.56 [19] . The risk of childhood brain cancer was studied in relation to parental exposure to pesticides among 154 children diagnosed with astrocytoma and 158 children diagnosed with primitive neuroectodermal tumors (PNET) in the United States and Canada between 1986 and 1989. Elevated risks of astrocytoma were found for paternal exposure (ever vs. never) to herbicides (odds ratio $(\mathrm{OR})=1.6,95 \% \mathrm{CI}: 1.0-$ $2.7)$ and fungicides (OR $=1.6,95 \% \mathrm{CI}: 1.0-2.6)$. The increased risk was also found for maternal exposure to insecticides (ever vs. never) ( $\mathrm{OR}=1.9,95 \% \mathrm{CI}: 1.1-3.3)$. No indication of an increased risk of PNET was found [20]. Shaw et al. [22] notice that paternal occupations, such as farming, forestry and fishing, have been suggested as possible risk factors for neural tube defects, e.g., anencephaly, spina bifida, cystica, craniorachischisis, iniencephaly (OR $=2.1,95 \%$ CI:1.3-3.3).

The study conducted by nine centers in seven countries (Canada, France, Australia, Spain, Italy, Israel, and the USA: Seattle, San Francisco, Los Angeles) covering 1218 cases of childhood brain tumors (CBT) and 2223 control subjects from the general population, showed that OR for CBT was elevated (OR $=2.3,95 \% \mathrm{CI}: 1.2-4.7)$ for children of mothers who in the preconception/prenatal period were in farm- or agriculture-related employment compared to those not involved in this kind of job. Increased ORs for CBT were observed in children of mothers who were employed as general farm workers $(\mathrm{OR}=3.8,95 \% \mathrm{CI}: 1.3-$ 11.0) [24].

More cases of brain tumor were observed $(\mathrm{n}=11)$ than expected $(\mathrm{n}=6.87)$ among 17357 children of Iowa pesticide applicators [21], but the results were not statistically significant (SIR $=1.60,95 \%$ CI:0.89-2.89). A small number of cases and limited statistical power may have pre- 
Table 1. Brain and nervous system tumors (studies published after Zahm and Ward's review [15])

\begin{tabular}{|c|c|c|c|c|}
\hline Study population & Study design & Results & $\begin{array}{c}\text { OR } \\
\operatorname{RR}(95 \% \mathrm{CI})\end{array}$ & Author, year \\
\hline $\begin{array}{l}\text { United States (Iowa) } \\
17357 \text { children of Iowa pesticide applicators }\end{array}$ & Cohort & $\begin{array}{l}\text { No association was found between } \\
\text { pesticide application by father } \\
\text { prenatally and brain tumors }\end{array}$ & $\mathrm{SIR}=1.60,95 \% \mathrm{CI}: 0.89-2.89$ & $\begin{array}{l}\text { Flower K, } \\
2004[21]\end{array}$ \\
\hline $\begin{array}{l}\text { United States (San Francisco, Los Angeles, } \\
\text { Seattle), Israel, Italy (Milan), Spain } \\
\text { (Valencia), Australia (Sydney), France (Paris), }\end{array}$ & Case-control & $\begin{array}{l}\text { Maternal exposure to pesticides } \\
\text { was associated with childhood brain } \\
\text { tumors }\end{array}$ & $\mathrm{OR}=2.0,95 \% \mathrm{CI}: 1.2-3.2$ & $\begin{array}{l}\text { Efird JT, } \\
2003[24]\end{array}$ \\
\hline
\end{tabular}

Canada (Winnipeg)

1218 cases of childhood brain tumors and

2223 controls

United States and Canada

154 children diagnosed with astrocytoma and 158 children diagnosed with primitive neuroectodermal tumors (PNET) between 1986-1989

United States and Canada

154 children diagnosed with astrocytoma and 158 children diagnosed with primitive neuroectodermal tumors (PNET) between 1986-1989

Sweden

27329 offspring of male pesticide applicators licensed 1965-1976

Sweden

235635 children born after two different

censuses (1976-1977; 1981-1982) followed

from the day they were born to their 15th

birthday or to 1993 whichever came first

Canada, British Columbia

23829 British Columbian sawmill workers employed for at least one continuous year between 1950 and 1985 in 11 sawmills that used chlorophenates (offspring cohort of 19674 children born at least 1 year after the initiation of employment in the period 1952-1988)

OR - odds ratio

$\mathrm{RR}$ - risk ratio;

SIR - standardized incidence ratio

Case-control Elevated risks of astrocytoma were observed for paternal exposure to three classes of pesticides, the results were not statistically significant Elevated risks of astrocytoma were observed for maternal exposure to two classes of pesticides, the result for non-agricultural fungicides was not statistically significant

$\mathrm{OR}=1.5,95 \% \mathrm{CI}: 0.9-2.4$

for insecticides

Wijngaarden E, $2003[20]$

(1.0-2.7

for herbicides

OR $=1.6,95 \%$ CI: $1.0-2.6$

for fungicides

OR $=1.9,95 \%$ CI: $1.1-3.3$

for insecticides

OR $=1.6,95 \%$ CI: $0.9-2.7$

for non-agricultural fungicides

Cohort

No association between childhood nervous system tumors and paternal exposure to pesticides

Cohort

Increased risk of nervous system tumors related to paternal occupational exposure to pesticides

SIR $=1.01,95 \%$ CI: 0.62-1.56

Rodvall Y, 2003 [19]

$\mathrm{RR}=3.65,95 \% \mathrm{CI}: 1.27-4.39$ Feychting M, in general $2001[18]$

Nested No increased risk of brain cancer in SIR $=1.3,95 \%$ CI: $0.6-2.5$

case-control children whose father was exposed to
chlorophenate fungicides

case-control children whose father was
chlorophenate fungicides
Wijngaarden E, $2003[20]$
$\mathrm{RR}=2.02,95 \% \mathrm{CI}: 1.08-4.16$ for paternal occupation before conception

Heacock $\mathrm{H}$, 2000 [23] vented from detecting association between pesticide use and childhood cancer.

The objective of the study conducted in Canada was to determine whether paternal occupational exposure to chlo- rophenol fungicides and their dioxin contaminants was associated with childhood cancer in the offspring of sawmill workers. Data were used from 23829 British Columbian sawmill workers employed for at least one continuous 
Table 2. Leukemia (studies published after Zahm and Ward's review [15])

\begin{tabular}{|c|c|c|c|c|}
\hline Study population & Study design & Results & OR, RR (95\%CI) & $\begin{array}{l}\text { Author, } \\
\text { year }\end{array}$ \\
\hline $\begin{array}{l}\text { United States, California } \\
2189 \text { cases of childhood cancer } \\
\text { and } 4335 \text { controls }\end{array}$ & Case-control & $\begin{array}{l}\text { Two commonly used pesticides } \\
\text { were associated with higher } \\
\text { leukemia risk when comparing } \\
\text { the highest and the lowest categories }\end{array}$ & $\begin{array}{l}\text { OR }=2.05,95 \% \text { CI:1.01-4.17 } \\
\text { for metam sodium } \\
\text { OR }=1.83,95 \% \text { CI:1.05-3.22) } \\
\text { for dicofol }\end{array}$ & $\begin{array}{l}\text { Reynolds P, } \\
2005[26]\end{array}$ \\
\hline $\begin{array}{l}\text { Sweden } \\
27329 \text { offspring of male pesticide } \\
\text { applicators licensed 1965-1976 }\end{array}$ & $\begin{array}{l}\text { Cohort- } \\
\text { retrospective }\end{array}$ & $\begin{array}{l}\text { No association between childhood } \\
\text { leukemia and paternal exposure } \\
\text { to pesticides (statistically } \\
\text { significantly reduced risk for } \\
\text { leukemia) }\end{array}$ & $\mathrm{SIR}=0.43,95 \% \mathrm{CI}: 0.19-0.86$ & $\begin{array}{l}\text { Rodvall Y, } \\
2003 \text { [19] }\end{array}$ \\
\hline $\begin{array}{l}\text { United States, California } \\
7143 \text { cases of invasive cancer among } \\
\text { children under } 15 \text { years of age } \\
\text { for 1988-1994 }\end{array}$ & Ecological & $\begin{array}{l}\text { Childhood leukemia was associated } \\
\text { with use of propargite }\end{array}$ & $\mathrm{RR}=1.48,95 \% \mathrm{CI}: 1.03-2.13$ & $\begin{array}{l}\text { Reynolds P, } \\
2002[8]\end{array}$ \\
\hline $\begin{array}{l}\text { United States, California } \\
162 \text { patients with diagnosed leukemia } \\
\text { and } 162 \text { matched controls selected } \\
\text { from birth registry }\end{array}$ & Case-control & $\begin{array}{l}\text { Exposure to pesticides } \\
\text { was associated with childhood } \\
\text { leukemia }\end{array}$ & $\begin{array}{l}\mathrm{OR}=2.8,95 \% \mathrm{CI}: 1.4-5.7 \text {, exposure } \\
\text { to pesticides from } 1 \text { year before birth } \\
\text { to } 3 \text { years after } \\
\mathrm{OR}=1.8,95 \% \mathrm{CI}: 1.1-3.1 \text {, exposure } \\
\text { to insecticides during } 3 \text { months before } \\
\text { pregnancy }\end{array}$ & $\begin{array}{l}\text { Ma X, } \\
2002[27]\end{array}$ \\
\hline $\begin{array}{l}\text { Sweden } \\
235635 \text { children born after two } \\
\text { different censuses (1976-1977; } \\
\text { 1981-1982) followed from the day } \\
\text { they were born to their } 15 \text { th birthday } \\
\text { or to } 1993 \text { whichever came first }\end{array}$ & Cohort & $\begin{array}{l}\text { No association between childhood } \\
\text { leukemia and paternal exposure } \\
\text { to pesticides }\end{array}$ & $\begin{array}{l}\mathrm{RR}=0.90,95 \% \mathrm{CI}: 0.37-2.19 \\
\text { in general } \\
\mathrm{RR}=1.12,95 \% \mathrm{CI}: 0.46-2.74 \\
\text { for paternal occupation before } \\
\text { conception }\end{array}$ & $\begin{array}{l}\text { Feychting } \\
\text { M, } 2001[18]\end{array}$ \\
\hline $\begin{array}{l}\text { Germany } \\
\text { Cases, } 1184 \text { children with leukemia, } \\
\text { controls, } 2588 \text { children }\end{array}$ & Case-control & $\begin{array}{l}\text { The use of pesticides on farms } \\
\text { by both parents was weakly related } \\
\text { to childhood leukemia }\end{array}$ & $\mathrm{OR}=1.5,95 \% \mathrm{CI}: 1.0-2.2$ & $\begin{array}{l}\text { Meinert R, } \\
2000[28]\end{array}$ \\
\hline $\begin{array}{l}\text { Canada, British Columbia; } \\
23829 \text { British Columbian sawmill } \\
\text { workers employed for at least one } \\
\text { continuous year between } 1950 \\
\text { and } 1985 \text { in } 11 \text { sawmills that used } \\
\text { chlorophenates (offspring cohort of } 19 \\
674 \text { children born at least } \\
1 \text { year after starting employment by } \\
\text { father in the years 1952-1988) }\end{array}$ & $\begin{array}{l}\text { Nested case- } \\
\text { control }\end{array}$ & $\begin{array}{l}\text { No increased risk for brain cancer } \\
\text { in children whose father was exposed } \\
\text { to chlorophenate fungicides }\end{array}$ & SIR $=1.0,95 \%$ CI:0.5-1.8 & $\begin{array}{l}\text { Heacock H, } \\
2000[23]\end{array}$ \\
\hline $\begin{array}{l}\text { Canada, Montreal } \\
491 \text { cases of childhood leukemia } \\
\text { compared to as many controls. } \\
\text { In } 123 \text { cases the gene-environment } \\
\text { interaction between child genotype } \\
\text { and maternal exposure during } \\
\text { pregnancy as well as child exposure } \\
\text { after birth was evaluated }\end{array}$ & Case-control & $\begin{array}{l}\text { Maternal use of pesticides was } \\
\text { associated with childhood leukemia } \\
\text { Increased CYP1A1M1 mutations } \\
\text { among cases of mothers who used } \\
\text { pesticides during pregnancy } \\
\text { Increased CYP1A1M2 mutations } \\
\text { among cases of mothers who used } \\
\text { pesticides during pregnancy }\end{array}$ & $\begin{array}{l}\text { OR }=1.83,95 \% \mathrm{CI}: 1.31-2.57 \text { for } \\
\text { herbicides (frequency of use, } 1-5 \text { times) } \\
\text { OR }=4.01,95 \% \mathrm{CI}: 1.12-14.32 \text { for plant } \\
\text { insecticides (frequency }>5 \text { times) } \\
\text { OR }=1.65,95 \% \mathrm{CI}: 1.07-2.54 \\
\text { for products against tree (1-5 times) } \\
\text { OR }=5.02,95 \% \mathrm{CI}: 1.00-25.09 \\
\text { for products against mites and spiders } \\
\text { OR }=5.55,95 \% \mathrm{CI}: 1.36-22.67 \\
\text { for products against outdoor insecticides } \\
\text { OR = 4.73, 95\%CI:1.18-18.53 } \\
\text { for products against cockroaches and ants }\end{array}$ & $\begin{array}{l}\text { Infante- } \\
\text { Rivard C, } \\
1999 \text { [29] } \\
\\
\text { S }\end{array}$ \\
\hline
\end{tabular}

OR - odds ratio; $\quad$ RR - risk ratio; $\quad$ SIR - standardized incidence ratio.


year between 1950 and 1985 in 11 sawmills that used chlorophenates (an offspring cohort of 19674 children born at least 1 year after starting employment by father in the years 1952-1988). A case-control analysis of the effects of paternal cumulative exposure and windows of exposure on the risk of cancer development in the offspring showed 40 cases of cancer during 259919 person-years of follow-up. SIR for brain cancer was 1.3, 95\%CI:0.6-2.5 [23].

\section{Leukemia(s)}

Zahm and Ward [15] reviewed one cohort and 17 casecontrol studies, which investigated a possible role of pesticides in the development of leukemias (acute lymphocytic leukemia, acute nonlymphocytic leukemia, acute myelogenous leukemia and chronic myelogenous leukemia). The majority of these studies reported elevated risks among children whose parents were occupationally exposed to pesticides or used pesticides in their homes or gardens. However, only one study analyzed the exposure to specific pesticides and the risk of childhood leukemia [25]. Scheele et al. [25] found no significant differences in levels of DDT, 1,1,1-trichloro-2,2-bis(p-chlorophenyl)ethylene, hexachlorobenzene, hexachlorocyclohexane or dieldrin in the bone marrow of childhood leukemia cases at the diagnosis compared to controls.

Recently, 4 studies have been published reporting the elevated risk of childhood leukemia associated with exposure to pesticides (environmental exposure and pesticides control services at home) (Table 2).

An ecological study carried out in agricultural region of California showed that the incidence of childhood leukemia (acute lymphocytic leukemia, acute nonlymphocytic leukemia) was significantly elevated $(\mathrm{RR}=1.48$, 95\% CI:1.03-2.13) with the highest use of insecticide propargite [8]. The same authors conducted a populationbased case-control study of early childhood cancer (age, 0-4 years) among California children born between 1990 and 1997 and mother's residential proximity to agricultural applicators of pesticides at the time of child's birth. Comparing the highest and the lowest categories; metam sodium $(\mathrm{OR}=2.05,95 \% \mathrm{CI}: 1.01-4.17)$ and dicofol $(\mathrm{OR}=$ 1.83, 95\% CI:1.05-3.22) were associated with the increased risk of leukemia (acute lymphocytic leukemia, acute nonlymphocytic leukemia) [26].

Another recent study conducted by Ma et al. [27] pointed out that the risk of childhood leukemia (mostly lymphoblastic leukemia) was significantly increased $(\mathrm{OR}=2.8$, 95\%CI:1.4-5.7) when professional pesticide control services were used in the home from 1 year before birth to 3 years after birth. Exposure in the first two years of life was associated with the highest risk (OR = 3.6, 95\%CI:1.6-8.3). Odds ratio for exposures to insecticides was the highest for exposures during pregnancy (OR $=2.1,95 \% \mathrm{CI}: 1.3-3.5)$. Also insecticide exposures early in the life appear to be more significant than later exposures. More frequent exposure to insecticides was associated with the elevated risk of leukemia.

A statistically significant reduction in the risk for leukemia (SIR $=0.43$, 95\%CI:0.19-0.86) was found among children born to Swedish male pesticide applicators [19]. Also Flower et al. [21] noticed more expected $(\mathrm{n}=9.88)$ than observed $(n=9)$ cases of leukemia related to paternal exposure to pesticides. Meinert at al. [28] found that the use of pesticides on farms was weakly related to childhood leukemia $(\mathrm{OR}=1.5,95 \% \mathrm{CI}: 1.0-2.2)$, while their use in gardens was not $(\mathrm{OR}=1.0,95 \% \mathrm{CI}: 0.8-1.2)$. No association between childhood leukemia and paternal exposure to pesticides prior to conception was found in the Swedish study. [18]. Also Heacock et al. [23] found no relation between paternal exposure to chlorophenate fungicides and the elevated risk of leukemia in offspring (SMR $=1.0,95 \% \mathrm{CI}: 0.5-1.8$ ).

With regard to cancer in general and childhood cancer in particular, the gene-environment interaction becomes a major concern. Population-based case-control study [29] showed the interaction between CYP1A1M1 and CYP1AM2 mutations and the occurrence of acute lymphocytic leukemia after exposure of pregnant women or their children to insecticides. In mothers who during pregnancy used products against mites and spiders $(\mathrm{OR}=5.02$, 95\% CI:1.00-25.09) and outdoor insecticides (OR $=5.55$, 95\%CI:1.36-22.67), increased CYP1A1M1 mutations, and in those who used pesticides against cockroaches and ants $(\mathrm{OR}=4.73,95 \% \mathrm{CI}: 1.18-18.53)$ increased CYP1A1M2 mutations were found. 


\section{Neuroblastoma}

Neuroblastoma is a neoplasm derived from embryonic neural crest cells. It is the most common tumor occurring in the first year of life and accounts for 8-10\% of all childhood tumors [30]. Relatively little is known about etiologic factors for neuroblastoma. The young age at the onset of most cases indicates the need to investigate exposures and events occurring before conception and during gestation in addition to genetic determinants [31]. The severity of neuroblastoma is characterized by asymptomatic tumors that spontaneously change to rapidly progressing tumors poorly responding to aggressive treatment and often leading to death [30].

Zahm and Ward [15] found little evidence that supports the role of pesticides in the etiology of this tumor, four studies showed decreased risks, two insignificant results and only one significant positive results. Exposure to chlordane was associated with neuroblastoma in two case reports [12,32]. Recent studies of the association between childhood neu- roblastoma and exposure to pesticides are presented in Table 3. The association was confirmed by three studies [33-35], whereas insignificant results were found in only one [21]. The effects were related to parental occupational exposure $[21,33]$ and the use of pesticides in households and gardens [34]. Another study [35] published in 1996, but not included in Zahm and Ward's review [15] showed that parental environmental exposure to herbicides and pesticides was associated with the increased risk of neuroblastoma $(\mathrm{RR}=4.2,95 \% \mathrm{CI}: 1.4-12.9)$. The study was based on the data derived from the German Childhood Cancer Registry [35].

The study of mothers occupationally exposed to insecticides, conducted in New York State (out of New York City), included 183 histologically confirmed neuroblastoma cases aged 0-14 years and 372 controls [33]. Similarly, a cohort of 17357 children of Iowa pesticide applicators revealed more cases $(n=3)$ than expected $(n=2.39)$ of neuroblastoma $(\mathrm{SIR}=1.26,95 \% \mathrm{CI}: 0.40-3.89)$, however,

Table 3. Neuroblastoma (studies published after Zahm and Ward's review [15])

\begin{tabular}{|c|c|c|c|c|}
\hline Study population & Study design & Results & OR, RR $(95 \% \mathrm{CI})$ & $\begin{array}{l}\text { Author, } \\
\text { year }\end{array}$ \\
\hline $\begin{array}{l}\text { United States (Iowa) } \\
17357 \text { children of Iowa pesticide } \\
\text { applicators }\end{array}$ & Cohort & $\begin{array}{l}\text { No association was found between } \\
\text { pesticide application by father } \\
\text { prenatally and neuroblastoma }\end{array}$ & $\mathrm{SIR}=1.25,95 \% \mathrm{CI}: 0.40-3.89$ & $\begin{array}{l}\text { Flower K, } \\
2004 \text { [21] }\end{array}$ \\
\hline $\begin{array}{l}\text { United States, Canada } \\
538 \text { cases of neuroblastoma } \\
\text { and } 504 \text { controls }\end{array}$ & Case-control & $\begin{array}{l}\text { Pesticides used in garden and home } \\
\text { by both parents were associated } \\
\text { with neuroblastoma }\end{array}$ & $\begin{array}{l}\text { OR }=1.9,95 \% \mathrm{CI}: 1.1-3.2 \text { for in-house } \\
\text { use of pesticides by both parents } \\
\text { (neuroblastoma among children } 1 \text { year } \\
\text { old and older) } \\
\text { OR }=2.2,95 \% \mathrm{CI}: 1.3-3.6 \text { for using } \\
\text { pesticides in the garden by both parents } \\
\text { (neurobalastoma among children } 1 \text { year } \\
\text { old and older) } \\
\text { OR = 2.2, 95\%CI: } 1.1-4.3 \text { for } \\
\text { used herbicides and insecticides } \\
\text { (neurobalastoma among children } 1 \text { year } \\
\text { old and older) }\end{array}$ & $\begin{array}{l}\text { Daniels JL, } \\
2001[34]\end{array}$ \\
\hline $\begin{array}{l}\text { United States (New York State) } \\
183 \text { neuroblastoma cases } \\
\text { (aged } 0-14 \text { years) between 1976-1987 } \\
\text { and } 372 \text { controls }\end{array}$ & Case-control & $\begin{array}{l}\text { Odds ratio was significantly elevated } \\
\text { for maternal reporting } \\
\text { of occupational exposure } \\
\text { to insecticides }\end{array}$ & $\mathrm{OR}=2.3,95 \% \mathrm{CI}: 1.4-3.7$ & $\begin{array}{l}\text { Kerr AM, } \\
2000[33]\end{array}$ \\
\hline $\begin{array}{l}\text { Germany } \\
\text { Cases of neuroblastoma born in } 1988 \\
\text { and reported with neuroblastoma } \\
\text { to the German Childhood Cancer } \\
\text { Registry until March } 1992 \text {, } \\
\text { controls-healthy children }\end{array}$ & Case-control & $\begin{array}{l}\text { Paternal exposure to herbicides } \\
\text { and pesticides was associated } \\
\text { with the occurrence } \\
\text { of neuroblastoma }\end{array}$ & $\mathrm{RR}=4.2,95 \% \mathrm{CI}: 1.4-12.9$ & $\begin{array}{l}\text { Michaelis J, } \\
1996 \text { [35] }\end{array}$ \\
\hline
\end{tabular}

OR - odds ratio; $\quad$ RR - risk ratio; $\quad$ SIR - standardized incidence ratio. 
the power of the study was not sufficient for conclusive statistical evaluation [21].

Daniels et al. [34] found that pesticides used in home and garden by both parents (residential exposure) were modestly associated with neuroblastoma in children $(\mathrm{OR}=1.6$, 95\%CI:1.0-2.3, OR=1.7, 95\%CI:0.9-2.1). Garden and in-house use of pesticides by both parents was associated with the increased risk of neuroblastoma among children 1 year old and older $(\mathrm{OR}=2.2,95 \% \mathrm{CI}: 1.3-3.6$ and $\mathrm{OR}=1.9,95 \% \mathrm{CI}: 1.1-3.2$, respectively), however the use of herbicides in garden especially contributed to the elevated risk.

\section{Non-Hodgkin's lymphoma and other lymphomas}

In Zahm and Ward's review [15], the relationship between pesticides and childhood non-Hodgkin's lymphoma was investigated in one case report, six case-controls and one cohort study. The results indicated that childhood nonHodgkin's lymphoma might be associated with exposure to pesticides. However, none of these studies allowed for indicating specific pesticides, which can cause this type of cancer. Two recent studies have been focused on the household exposure $[28,36]$ and two others on the effects of occupational exposure $[19,21]$. The increased risk of childhood lymphomas was found in one German [28] and two North American studies [21,36], whereas elevated risk was observed in the study conducted in Sweden [19] (Table 4).

Buckley et al. [36] found a significant association between the risk of non-Hodgkin's lymphoma and the increased (almost everyday) in-house use of insecticides by mothers, professional exterminations of insects in the household and postnatal exposure to pesticides and herbicides.

A case-control study based on interviews with parents of children below 15 years of age, conducted in West Germany in 1993-1997, revealed an association between residential use of insecticides and childhood lymphoma [28]. Frequency of both extermination of insects by professional pest controllers (OR $=2.6,95 \% \mathrm{CI}: 1.2-5.7)$ and paternal use of household insecticides were a significant risk factor for non-Hodgkin's lymphoma.

The aforesaid prospective study [21] conducted among 17357 children of Iowa pesticide applicators showed the increased risk of all lymphomas (SIR $=2.18$, 95\%CI:1.13-4.19) and the increased risk of Hodgkin's lymphoma (SIR $=2.56,95 \% \mathrm{CI}: 1.06-6.14)$. The increased

Table 4. Non-Hodgkin's lymphoma and all lymphomas (studies published after Zahm and Ward's review [15])

\begin{tabular}{|c|c|c|c|c|}
\hline Study population & Study design & Results & OR, RR, SIR (95\%CI) & $\begin{array}{l}\text { Author, } \\
\text { year }\end{array}$ \\
\hline $\begin{array}{l}\text { United States (Iowa) } \\
17357 \text { children of Iowa pesticide } \\
\text { applicators }\end{array}$ & Cohort & $\begin{array}{l}\text { The risk of all lymphomas increased like } \\
\text { the risk of Hodgkin's lymphoma } \\
\text { (pesticides used by father prenatally) }\end{array}$ & $\begin{array}{l}\text { SIR = 2.18, 95\%CI:1.13-4.19 } \\
\text { for all lymphomas } \\
\text { SIR = 2.56, 95\%CI:1.06-6.14 } \\
\text { for non Hodgkin's lymphoma }\end{array}$ & $\begin{array}{l}\text { Flower K, } \\
2004[21]\end{array}$ \\
\hline $\begin{array}{l}\text { Sweden } \\
27329 \text { offspring of male pesticide } \\
\text { applicators licensed 1965-1976 }\end{array}$ & $\begin{array}{l}\text { Cohort- } \\
\text { retrospective }\end{array}$ & $\begin{array}{l}\text { No association between non-Hodgkin's } \\
\text { lymphoma and paternal exposure } \\
\text { to pesticides }\end{array}$ & $\mathrm{SIR}=0.63,95 \% \mathrm{CI}: 0.13-1.83$ & $\begin{array}{l}\text { Rodvall Y, } \\
2003 \text { [19] }\end{array}$ \\
\hline $\begin{array}{l}\text { Germany } \\
\text { Cases, } 234 \text { children with non- } \\
\text { Hodgkin's lymphoma, controls, } \\
2588 \text { children }\end{array}$ & Case-control & $\begin{array}{l}\text { Residential use of pesticides } \\
\text { was associated with childhood } \\
\text { lymphoma }\end{array}$ & $\begin{array}{l}\text { OR }=2.6,95 \% \mathrm{CI}: 1.2-5.7 \text { for } \\
\text { extermination of insects } \\
\text { by professional pest controllers } \\
\mathrm{p}=0.02 \text { for parental use of household } \\
\text { insecticides }\end{array}$ & $\begin{array}{l}\text { Meinert R, } \\
2000[28]\end{array}$ \\
\hline $\begin{array}{l}\text { United States } \\
268 \text { children who developed non- } \\
\text { Hodgkin's lymphoma or leukemia } \\
\text { with selected regional controls }\end{array}$ & Case-control & $\begin{array}{l}\text { A significant association between risk } \\
\text { of non-Hodgkin's lymphoma } \\
\text { and pesticide use at home }\end{array}$ & $\begin{array}{l}\mathrm{OR}=7.3 ; \mathrm{p}=0.05 \text { for reported } \\
\text { pesticide use at home } \\
\mathrm{OR}=3.0 ; \mathrm{p}=0.002 \text { for professional } \\
\text { exterminations of insects in the } \\
\text { household } \\
\text { OR }=2.4 ; \mathrm{p}=0.001 \text { for postnatal } \\
\text { exposure }\end{array}$ & $\begin{array}{l}\text { Buckley JD, } \\
2000[36]\end{array}$ \\
\hline
\end{tabular}

OR - odds ratio; $\quad$ RR - risk ratio; $\quad$ SIR - standardized incidence ratio. 
risk of Hodgkin's lymphoma was also detected among children whose father did not use chemically resistant gloves $(\mathrm{OR}=1.98,95 \% \mathrm{CI}: 1.05-3.76)$ [21].

On the other hand, Rodvall et al. [19] did not find an increased risk of non-Hodgkin's lymphoma ( $\mathrm{SIR}=0.63$, 95\%CI:0.13-1.83) and Hodgkin's disease (SIR $=1.36$, 95\%CI:0.44-3.17) among children of Swedish male pesticide applicators.

\section{Wilms' tumor}

Wilms' tumor is an embryonal malignancy, which arises from immature kidney [37]. The rare incidence of Wilms' tumor has made epidemiological studies difficult to carry out. The frequency of Wilms' tumor varies with ethnicity; the incidence is two to three times higher in Blacks than in Asians [38].

Zahm and Ward [15] in their 1998 review found two studies based on the subjects' reports of household or occupational and parental agricultural use of pesticides, which showed elevated risks of Wilms' tumor [39,40]. These findings were not confirmed by other 3 studies of pesticide exposure determined by paternal occupational title or imputed from occupational titles using job-exposure matrices [41-43]. One study investigated the risk associated with exposure to DDT, ethylene dibromide and endrin, however, no indication for the elevated risk of Wilms' tumors was found [43].
Two studies [21,44] have been published after Zahm and Ward's review [15] (Table 5). Neither of them provided support for the role of pesticide exposure in the etiology of Wilms' tumor.

A large case-control study of 177 children under 10 years of age with Wilms' tumor diagnosed between 1988 and 1994, and 2006 control children was conducted in Germany. Child's exposure to pesticides in gardens and on farms, in-house use of insecticides, maternal occupational exposure to pesticides and paternal occupational exposure to pesticides after birth was not associated with the occurrence of Wilms' tumor [44].

The prospective study of Flower et al. indicated that more cases of Wilms' tumor were observed $(\mathrm{n}=3)$ than expected $(\mathrm{n}=1.92)(\mathrm{SIR}=1.56,95 \%$ CI:0.50-4.84), but the number of cases was too small for a meaningful statistical analysis.

\section{Other cancers}

Zahm and Ward [15] in their review noticed that due to very few reports on other cancers, e.g., soft-tissue sarcoma, testicular cancer, retinoblastoma, and bone tumors, little can be concluded from them about a possible role of pesticides in their etiology.

Recently published studies have revealed some excess of retinoblastoma and bone tumor, soft tissue tumors [21], kidney cancer [45], testicular cancer [19] and germ-cell tumor [46], however, the majority of their results did not reach statistical significance. A positive association between ma-

Table 5. Wilms' tumor (studies published after Zahm and Ward's review [15])

\begin{tabular}{|c|c|c|c|c|}
\hline Study population & Study design & Results & OR, RR (95\%CI) & $\begin{array}{c}\text { Author, } \\
\text { year }\end{array}$ \\
\hline $\begin{array}{l}\text { United States (Iowa) } \\
17357 \text { children of Iowa } \\
\text { pesticide applicators }\end{array}$ & Cohort & $\begin{array}{l}\text { No association was found between } \\
\text { pesticide application by father } \\
\text { prenatally and Wilms' tumor }\end{array}$ & $\mathrm{SIR}=1.56,95 \% \mathrm{CI}: 0.50-4.84$ & $\begin{array}{l}\text { Flower K, } \\
2004 \text { [21] }\end{array}$ \\
\hline $\begin{array}{l}\text { Germany } \\
177 \text { children under } 10 \text { years } \\
\text { of age with Wilms' tumor } \\
\text { diagnosed between 1988-1994 } \\
\text { and } 2006 \text { controls }\end{array}$ & $\begin{array}{l}\text { Case-control } \\
4\end{array}$ & $\begin{array}{l}\text { No association was found between } \\
\text { exposure to pesticides } \\
\text { and Wilms' tumor }\end{array}$ & $\begin{array}{l}\text { OR }=0.80,95 \% \mathrm{CI}: 0.44-1.47 \text { for child's } \\
\text { exposure to pesticides in garden } \\
\text { OR }=0.84,95 \% \mathrm{CI}: 0.32-2.25 \text { for child's } \\
\text { exposure to pesticides on farms } \\
\text { OR }=1.27,95 \% \mathrm{CI}: 0.78-2.08 \text { for in-house } \\
\text { use of insecticides } \\
\text { OR }=2.52,95 \% \mathrm{CI}: 0.50-12.6 \text { for maternal } \\
\text { occupational exposure to pesticides ever } \\
\text { OR }=0.97,95 \% \mathrm{CI}: 0.39-2.37 \text { for paternal } \\
\text { occupational exposure to pesticides after birth }\end{array}$ & $\begin{array}{l}\text { Schüz J, } \\
2001 \text { [44] }\end{array}$ \\
\hline
\end{tabular}

OR - odds ratio; 
ternal exposure to herbicides during the postnatal period and the risk of germ-cell tumor was found in girls (OR = 2.3, 95\% CI:1.0-5.2), but the results were not statistically significant. An inverse association between parental exposure to pesticides during the postnatal period and germ-cell tumors was found in boys ( $\mathrm{OR}=0.2,95 \% \mathrm{CI}: 0.1-1.0)$ [46]. The studies conducted in England and Wales showed that paternal occupational exposure to pesticides (employment in agriculture) might be related to kidney cancer in offspring [47]. Records of 16703 childhood deaths occurring during
1959-1963, 1970-1978 and 1979-1990 in England and Wales have been analyzed. There were 5270 deaths, of which 449 were due to cancer, among the offspring of men with potential occupational exposure to pesticides. Associations were assessed using proportional mortality ratio (PMR), with adjustment for age, year of death and paternal social class. Of the childhood cancers previously linked with potential paternal occupational exposure to pesticides, only for kidney cancer statistically significant excess was found (PMR = 1.59, 95\% CI:1.18-2.15, based on 42 deaths) (Table 6).

Table 6. Different cancers (studies published after Zahm and Ward's review [15])

\begin{tabular}{|c|c|c|c|c|}
\hline Study population & Study design & Results & OR, RR (95\%CI) & $\begin{array}{c}\text { Author, } \\
\text { year }\end{array}$ \\
\hline $\begin{array}{l}\text { United States } \\
253 \text { cases, } 394 \text { controls } \\
\text { (Children Oncology Group, } \\
\text { 1993-2001) }\end{array}$ & Case-control & $\begin{array}{l}\text { This study did not provide strong } \\
\text { evidence supporting the relation } \\
\text { between parental pesticide exposure } \\
\text { in workplace and the risk } \\
\text { of germ-cell tumors among offspring. }\end{array}$ & $\begin{array}{l}\text { Childhood germ-cell tumor and maternal exposure: } \\
\text { - before pregnancy OR }=1.0,95 \% \mathrm{CI}: 0.8-1.4 \\
\text { - during pregnancy OR }=1.1,95 \% \mathrm{CI}: 0.7-1.6 \\
\text { - after the child was born OR }=1.3,95 \% \mathrm{CI}: 0.9-1.8 \\
\text { Childhood germ-cell tumor and paternal exposure: } \\
\text { - before pregnancy OR }=0.9,95 \% \mathrm{CI}: 0.7-1.2 \\
\text { - during pregnancy OR }=0.8,95 \% \mathrm{CI}: 0.5-1.2 \\
\text { - after the child was born OR }=0.8,95 \% \mathrm{CI}: 0.5-1.3 \\
\text { Maternal exposure to herbicides during the postnatal } \\
\text { period and the risk of germ-cell tumor in girls } \\
\text { OR = 2.3, } 95 \% \mathrm{CI}: 1.0-5.2 \\
\text { Parental exposure to pesticides during the postnatal } \\
\text { period and germ-cell tumors in boys } \mathrm{OR}=0.2 \text {, } \\
95 \% \mathrm{CI}: 0.1-1.0\end{array}$ & $\begin{array}{l}\text { Chen Z, } \\
2005 \text { [46] }\end{array}$ \\
\hline $\begin{array}{l}\text { United States (Iowa) } \\
17357 \text { children of Iowa } \\
\text { pesticide applicators }\end{array}$ & Cohort & $\begin{array}{l}\text { No association was found between } \\
\text { pesticide application by father } \\
\text { prenatally and retinoblastoma, } \\
\text { bone tumor, soft tissue tumors, } \\
\text { germ-cell tumors }\end{array}$ & $\begin{array}{l}\text { SIR }=1.63,95 \% \text { CI: } 0.41-6.53 \text { for retinoblastoma } \\
\text { SIR }=2.19,95 \% \text { CI: } 0.82-5.84 \text { for bone tumors } \\
\text { SIR }=1.17,95 \% \text { CI: } 0.38-3.62 \text { for soft tissue tumor } \\
\text { SIR }=2.34,95 \% \text { CI: } 0.88-6.24 \text { for germ cell tumors }\end{array}$ & $\begin{array}{l}\text { Flower K, } \\
2004[21]\end{array}$ \\
\hline $\begin{array}{l}\text { Sweden } \\
27329 \text { offspring of male } \\
\text { pesticide applicators } \\
\text { licensed } 1965-1976\end{array}$ & $\begin{array}{l}\text { Cohort- } \\
\text { retrospective }\end{array}$ & $\begin{array}{l}\text { No association between Hodgkin's } \\
\text { disease, testicular cancer } \\
\text { and paternal exposure to pesticides }\end{array}$ & $\begin{array}{l}\text { SIR }=1.36,95 \% \text { CI: } 0.44-3.17 \text { for Hodgkin's disease } \\
\text { SIR }=1.19,95 \% \text { CI: } 0.13-4.28 \text { for testicular cancer }\end{array}$ & $\begin{array}{l}\text { Rodvall Y, } \\
2003[19]\end{array}$ \\
\hline $\begin{array}{l}\text { England, county } \\
\text { of Cumbria } \\
298188 \text { live births } \\
(1950-1993)\end{array}$ & $\begin{array}{l}\text { Cohort- } \\
\text { retrospective }\end{array}$ & $\begin{array}{l}\text { No association between childhood } \\
\text { kidney cancer and paternal } \\
\text { employment in agriculture }\end{array}$ & $\begin{array}{l}\text { OR }=0.88,95 \% \text { CI: } 0.20-3.84 \text { for kidney cancer, } \\
\text { age } 1-15 \text { years at diagnosis }\end{array}$ & $\begin{array}{l}\text { Pearce NT, } \\
2000[45]\end{array}$ \\
\hline $\begin{array}{l}\text { England, Wales } \\
167703 \text { childhood deaths } \\
\text { occurring during } \\
\text { 1959-1963,1970-1978 } \\
\text { and 1979-1990; 5270 deaths } \\
\text { among the offspring of men } \\
\text { with potential occupational } \\
\text { exposure to pesticides, } \\
\text { of which } 449 \text { were due } \\
\text { to cancer }\end{array}$ & $\begin{array}{l}\text { Cohort- } \\
\text { retrospective }\end{array}$ & $\begin{array}{l}\text { Association were assessed using } \\
\text { proportional mortality ratio (PMR). } \\
\text { Of childhood cancers previously linked } \\
\text { with potential paternal occupational } \\
\text { exposure to pesticides, only for kidney } \\
\text { cancer statistically significant excess } \\
\text { was found }\end{array}$ & PMR $=1.59,95 \%$ CI:1.18-2.15 for kidney cancer & $\begin{array}{l}\text { Fear NT, } \\
1998[47]\end{array}$ \\
\hline
\end{tabular}

OR - odds ratio; $\quad$ RR - risk ratio; $\quad$ SIR - standardized incidence ratio. 


\section{DISCUSSION}

The major difficulties in epidemiological studies of childhood cancer result from the relative rarity of specific childhood cancers. This becomes a particular problem if one intends to study cancers other than leukemias and brain tumors in children. This factor has played the single most important role in limiting our information on causes of childhood cancers. One of the ways to overcome this problem is the case-control study design. However, this kind of studies is sensitive to many limitations. The key problem is the evaluation of exposure, especially the environmental one. Some other difficulties include selection and recall biases. Other designs like ecological studies have even more limitations and they are rather used for the formulation of hypotheses than for testing. Cohort studies provide much more opportunities for valid exposure estimates, however, their size is usually too small to provide conclusive results in the childhood cancer risk assessment.

\section{Limited sample size}

In the majority of studies presented in Zahm and Ward's review [15], the numbers of cases and controls were small. Recently, several larger studies have been conducted, which allowed to evaluate the timing of exposure or multiple pesticide exposure. A larger cohort study was conducted by Feychting et al. [18] in 2001. It covered 235635 children born shortly after two different censuses in Sweden. Reynolds et al. [8] conducted an ecological study, which included 7143 cases and very recently the same authors performed another study of 2189 cases and 4335 controls [26] A large (1218 cases and 2223 controls) international study of parental occupational exposure and brain tumor, comprising participants from different countries, was performed by Efird et al. [24].

\section{Challenges of case-control studies}

Two key challenges associated with case-control design are control selection and exposure assessment [48]. The consequence of conducting case-control studies is the loss of information associated with retrospective exposure assessment. Studies that identify cases as they are diagnosed (prospective case-control studies) avoid an additional delay associated with recruiting cases diagnosed before the initiation of data collection, but there is still a limit to the accuracy of exposure assessment for periods extending back as far as 15 years [9].

Selection bias is a major limitation in the design and interpretation of case-control studies. Only Kerr et al. [33] succeeded to reach in their study high participation rate of $85 \%$ for cases and $87 \%$ for controls, which can reduce the selection bias. In the study conducted by Ma et al. [27], controls were randomly selected from the California birth registry and the methodological evaluation indicated that birth certificate controls well represented the cases of population. In addition, this was one of the first studies specifically designed to address critical window of exposure, the timing of household pesticide exposures relative to child's conception and development. On the other hand, the study conducted in California was based on the sample of relatively small size (162 cases and 162 controls), which reduced its power to detect low level risk [27].

Another problem in case-control studies is a recall bias, a tendency among more highly motivated parents to overreport exposures, which could produce systematically elevated ORs for a wide range of exposures [36]. Also an interviewer bias might occur in the US study conducted by Kerr et al. [33], because the interviewers were not blinded as to the disease status of children whose mothers were interviewed. Interviewers may have more deeply studied exposures of cases than of controls.

\section{Exposure assessment based on non-specific categories}

In the majority of studies the subjects have just claimed the exposure to pesticides without giving their chemical names or specifying exposure duration and their authors have mostly relied on self-reported use of pesticides in households and gardens or parental occupational exposure. The highest exposure to pesticides can be found among workers involved in their manufacture, formulation and application either in agricultural or in public health sectors, but these jobs are rare. Many previous studies of childhood cancer were based on job titles, which is not a suitable method for identifying and quantifying 
exposure. Wijngaarden et al. [20] evaluated each job for exposure to insecticides, herbicides and fungicides and obtained information on each person's work history from job-specific questionnaire.

To improve the validity of exposure classification some researchers considered reports of both parents. The fact that both parents agreed about the use of pesticides would not necessarily indicate a higher exposure than the use reported by only one parent, but the use of pesticides confirmed by both parents increases confidence in the obtained information [34].

As yet childhood cancer has not been evaluated with respect to potential residential exposure to agricultural pesticides because respondents are unlikely to have specific knowledge about pesticide use on nearby fields [49]. Only data on the use of pesticides available from specific registers (e.g., California register, a pesticide database that includes detailed information on the active ingredient, quantity applied, acres treated, crop treated, and location for all agricultural pesticide applications) can overcome such difficulties.

\section{Interview-based assessment of exposure to specific pesticides (self-reported data)}

Occupational histories collected by personal interview provide more detailed information about occupational exposure than might be detected from occupations listed in birth certificates [33]. Therefore, it is advised that a useful structured questionnaire, addressing frequency and duration of exposure, be developed.

It is rather difficult to obtain accurate information on specific chemicals used many years ago through interviews that is why an unacceptable level of inaccuracy in recalling the types of chemicals and dates of their use can undoubtedly occur. Operations, such as purchasing of chemicals or their personal mixing and applying may improve the memory of farmers responsible for running their farms, and thus can significantly diminish the recall bias [50]. However, information on pesticide use based on a questionnaire is usually insufficient for valid dose assessment. Owing to carefully structured questionnaires a number of other factors associated with exposure levels might be identified, including duration and frequency of manual contact, application of active ingredients per surface area, spray pressure, wind speed and boom length [50].

\section{Assessment of exposure to specific pesticides}

Only in studies conducted by Reynolds et al. $[8,26]$ and Flower et al. [21] specific kinds of pesticides were evaluated (Table 7). The use of propargite, metam sodium and dicofol $[8,26]$ was associated with the increased risk of childhood leukemia. Flower et al. [21] found the relationship between the use of aldrin and the risk of childhood cancer in general. There was no association between the use of simazine, trifluralin and methyl bromide and increased risk of childhood leukemia [8].

The prospective approach is probably the only way to improve the quality of pesticide exposure data. It also allows to validate reports of farm holders by using biological monitoring methods [51].

\section{Timing of exposure}

Information on periods of higher risk might provide information on the mechanism by which a given cancer develops. Several studies have found a stronger effect of exposures before conception than during pregnancy $[18,29]$. On other hand some studies suggest that pesticides used during pregnancy were associated with childhood leukemia. [27,29]. Postnatal exposure to pesticides has been reported to be associated with non-Hodgkin's lymphoma [36], neuroblastoma [34], leukemia [26,27] and brain cancer [24]. In most of the studies, it is difficult to separate exposure before conception from exposure occurring during pregnancy or after the child was born. Five studies on childhood cancer and exposure to pesticides estimated critical windows of exposure. Ma et al. [27] investigated the exposure at any time from 1 year before birth to 3 years after, exposure during the second year of life, exposure 3 months before pregnancy and during pregnancy as well as the risk of childhood leukemia.

\section{Limitations of ecological studies}

Ecological study is a kind of study in which an aggregate of individuals rather than an individual person forms the unit of analysis. Even when an association is found between ex- 


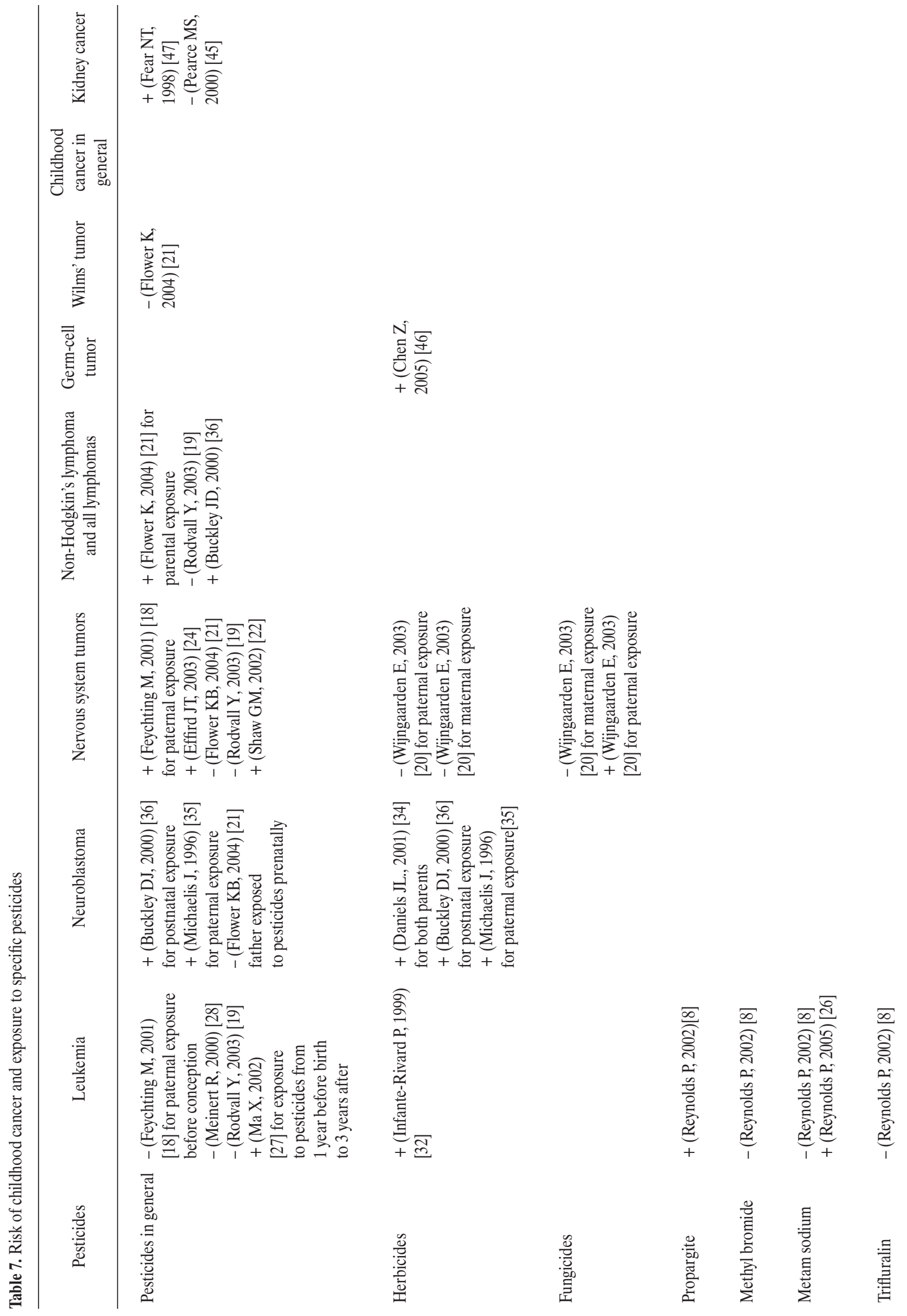




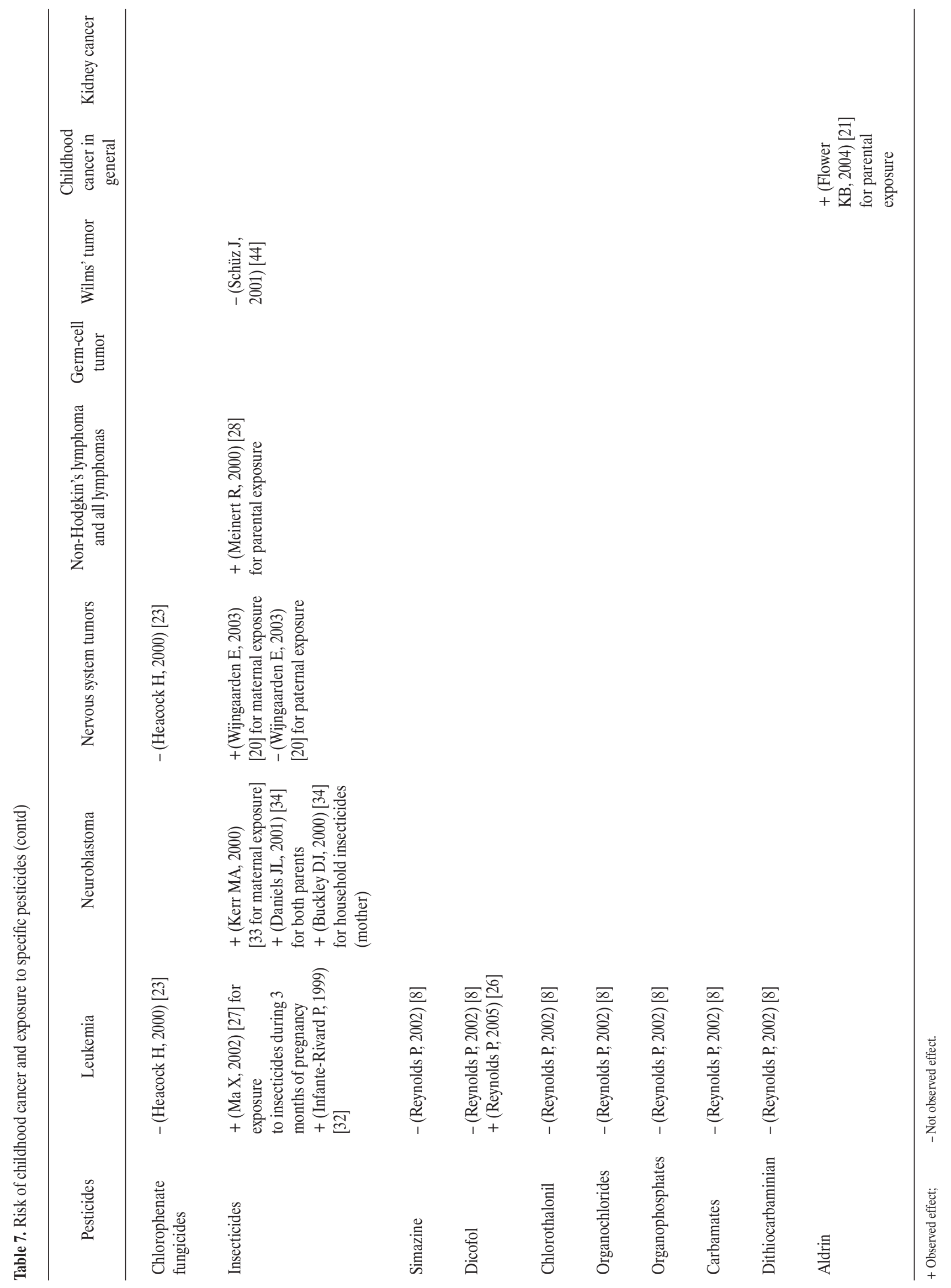


posure and disease, it is very difficult to assess the role of other factors which might be responsible for an increased risk and to control the effects of potential confounding factors.

An ecological study has recently been completed by Reynolds et al. [8]. It was based on childhood cancer incidence rates throughout California in relation to agricultural pesticide use. This kind of study has several limitations, including the the lack of data on potential confounding factors, the lack of information on residential stability, and a possible misclassification of group exposures. The study was based on the Pesticide Use Reporting Database maintained in the California Department of Pesticide Regulation that includes detailed information on the active ingredient, quantity applied, acres treated, crop treated and location for all agricultural pesticide applications in California. The records-based nature of the study made it feasible to include all cases occurring in the population of California.

\section{Cohort studies}

A major advantage of the cohort study approach is its best suitability for evaluating health outcomes of rare exposure. However, in a cohort study a very large number of exposed individuals have to be studied to detect an elevated risk of extremely rare cancer.

Few cohort studies have recently been published [18,19,21], however, they still fail to provide information on the type, dose, timing of parents' and occupational exposure. Validity of the results can be seriously affected by losses to follow-up and changes over time in diagnostic methods.

The strength of the study carried out by Feychting et al. [18] is that it is a population-based cohort study where all information about the exposure has been collected prior to cancer development. So there is no concern of recall bias. Moreover, the Swedish Population Registry was used to identify children with cancer and their parents, which means that selection bias is unlikely to affect the findings. The major weakness of this study is exposure assessment. The exposure classification was based on the occupational title and industry performed 2-26 months before the child's birth. The exposure may have changed since the occupational classification and the level of exposure may vary within an occupational title. An analysis of the specific subtypes of leukemia or nervous system tumors was not possible because of a small number of exposed cases (leukemia, $\mathrm{n}=5$ cases and nervous system tumors, $\mathrm{n}=11$ cases).

A large cohort of pesticide applicators was used in the study conducted by Rodvall et al. [19]. This cohort consisted of the most pesticide-exposed occupational group in Sweden. Individual confounding factors and details on pesticide exposure were not available for the pesticide applicators and their offspring. Flower et al. [21] identified information for 17357 children of Iowa pesticide applicators, but a small number of cases and limited statistical power may have prevented from detecting significant associations.

\section{CONCLUSION}

In the studies of the effects of exposure to pesticides and childhood cancer much emphasis has been laid on epidemiological investigations. However, despite high priority given to this issue and a considerable number of studies performed, the epidemiological methods employed so far have not significantly contributed to the assessment of childhood cancer and toxicity of pesticides. A major weakness of many epidemiological studies of pesticide health effects has been the difficulty in exposure assessment. Unfortunately, the solution to this problem cannot be expected in the near future. Until improvements are made in the classification of pesticide exposures, the results concerning health effects will be burden with the misclassification bias, which makes it difficult to draw valid conclusions about the safety of specific pesticides.

Although it has been recognized that the impact of exposure incurred during pregnancy frequently depends on the timing of those exposures, the majority of epidemiological studies do not distinguish between the exposure before conception, during pregnancy or after the child's birth. It is likely that genetic factors play an important role in the etiology of many childhood cancers. Children with genetic predisposition to cancer may be particularly sensitive to 
environmental carcinogenic exposure. The recent years have witnessed a rapid progress in the study design and performance. National-based cohorts provide a valuable basis for parental exposure studies. The use of national registers of birth defects is common in the Scandinavian countries, and probably remains the most instrumental in the area of developmental outcomes of the risk assessment, in particular when supplemented by more precise and relevant information in nested case-control studies $[52,53]$. The possibility of establishing large prospective cohorts of farming couples who plan procreation is definitely worth considering. An important advantage of this strategy is the possibility to investigate several interrelated outcomes for which the combined results may add inferential value and credibility. Cohorts open the potential for performing nested case-referent studies with better estimation of exposure parameters.

We might never develop the sound evidence of harmful effects of the use of specific pesticides and even less probable is that we obtain evidence that such exposure is harmless. On the other hand, information derived from epidemiological studies so far indicates the need to increase awareness among people exposed to pesticides about the association between agricultural work, use of pesticides and childhood cancer. We should simply apply the principle of prudence, just in case.

\section{REFERENCES}

1. Bearer CF. How children differ from adults? Environ Health Persp 1995;103 Suppl 6:7-12.

2. Pohl HR, Tylenda CA. Breast-feeding exposure of infants to selected pesticides: A public health viewpoint. Toxicol Ind Health 2000;16:65-77.

3. Weiss B, Amler S, Amler RW. Pesticides. Pediatrics 2004;113(4):1030-6.

4. Cooper SP, Darragh AR, Vernon SW, Stallones L, MacNaughton N, Robison T, et al. Ascertainment of pesticide exposures of migrant and seasonal farmworker children: findings from focus groups. Am J Ind Med 2001;40:531-7.

5. Freeman NCG, Jimenez M, Reed KJ, Gurunathan S, Edwards RD, Roy A, et al. Quantitative analysis of children's pesticide study. Annal Environ Epidemiol 2001;11:501-9.
6. Lu C, Knudson DE, Fisker-Anderson J, Fenske RA. Biological monitoring survey of organophosphorous pesticide exposure among preschool children in the Seattle metropolitan area. Environ Health Perspect 2001;109:299-303.

7. van der Jagt K, Tielemans E, Links J, Brouwer D. Effectiveness of personal protective equipment: relevance of dermal exposure to chlorpyrifos among pest control operators. J Occup Environ Hyg 2004;1(6):355-62.

8. Reynolds P, Von Behren J, Gunier RB, Goldberg DE, Hertz A, Harnly ME. Childhood cancer and agricultural pesticide use: an ecologic study in California. Environ Health Persp 2002;110(3):319-24.

9. Savitz DA. Environmental exposures and childhood cancer: our best may not be good enough. Am J Public Health 2001;91(4):562-3.

10. Zahm SH, Devesa SS. Childhood cancer: an overview of incidence trends and environmental carcinogens. Environ Health Prospect 1995;103 Suppl 6:177-84.

11. Schüz J, Spector LG, Ross JA. Bias in studies of parental self-reported occupational exposure and childhood cancer. Am J Epidemiol 2003;158(7):710-6.

12. Infante PF, Newton WA. Prenatal chlordane exposure and neuroblastoma. N Engl J Med 1975;293:308-12.

13. Reeves JD, Driggers DA, Kiley VA. Household insecticide associated aplastic anaemia and acute leukaemia in children. Lancet 1981;8241:300-8.

14. Borkhardt A, Wilda M, Fuchs U, Gortner L, Reiss I. Congenital leukaemia after heavy abuse of permethrin during pregnancy. Arch Dis Child Fetal Neonatal Ed 2003;88(5):436-7.

15. Zahm SH, Ward MH. Pesticides and childhood cancer. Environ Health Perspect 1998;106 Suppl 3:893-908.

16. Chadduck WM, Gollin SM, Gray BA, Norris IS, Araoz CA, Tryka AF. Gliosarcoma with chromosome abnormalities in the neonate exposed to hepatochlor: Neurosurgery 1987;21:557-9.

17. Davis JR, Brownson RC, Garcia R, Bentz BJ, Turner A. Family pesticide use and childhood brain cancer. Arch Environ Contam Toxicol 1993;24:87-92.

18. Feychting M, Plato N, Nise G, Ahlbom A. Paternal occupational exposures and childhood cancer. Environ Health Persp 2001;109(2):93-6.

19. Rodvall Y, Dich J, Wiklund K. Cancer risk in offspring of male pesticide applicators in agriculture in Sweden. Occup Environ Med 2003;60:798-801.

20. Van Wijngaarden E, Stewart PA, Olshan AF, Savitz DA, Bunin GR. Paternal occupational exposure to pesticides and childhood brain cancer. Am J Epidemiol 2003;157:989-97. 
21. Flower KB, Hoppin JA, Lynch CF, Blair A, Knott C, Shore DL, et al. Cancer risk and paternal pesticide application in children of agricultural health study participants. Environ Health Persp 2004;112(5):631-5.

22. Shaw GM, Olshan NV, Andrew F. Paternal occupational group and risk of offspring with neural tube defects. Paediatr Perinat Epidemiol 2002;16(4):328-33.

23. Heacock H, Hertzman C, Demers PA, Gallagher R, Hogg RS., Teschke K, et al. Childhood cancer in the offspring of male sawmill workers occupationally exposed to chlorophenate fungicides. Environ Health Perspect 2000;108(6):499-503.

24. Efird JT, Holly EA, Preston-Martin S, Mueller BA, Lubin F, Filippini G, et al. Farm-related exposures and childhood brain tumours in seven countries: results from the SEARCH International Brain Tumour Study. Pediatr Perinat Epidemiol 2003;17:201-11.

25. Scheele J, Teufel M, Niessen KH. Chlorinated hydrocarbons in the bone marrow of children: studies on their association with leukaemia. Eur J Pediatr 1992;151:802-5.

26. Reynolds P, Von Behren J, Gunier RB, Goldberg DE, Harnly M, Hertz A. Agricultural pesticide use and cancer in California. Epidemiology 2005;16(1):93-100.

27. Ma X, Buffler PA, Gunier RB, Dahl G, Smith MT, Reinier K, et al. Critical windows of exposure to household pesticides and risk of childhood leukemia. Environ Health Persp 2002;110(9):955-60.

28. Meinert R, Schuz J, Kaletsch U, Kaatsch P, Michaelis J. Leukemia and non-Hodgkin's lymphoma in childhood and exposure to pesticides: results of a register-based case-control study in Germany. Am J Epidemiol 2000;15(7):639-46.

29. Infante-Rivard C, Labuda D, Krajinovic M, Sinnett D. Risk of childhood leukemia associated with exposure to pesticides and with gene polymorphism. Epidemiology 1999;10(5):481-7.

30. Brodeur GM, Castleberry RP. Neuroblastoma. In: Piazzo PA, Paplack DG, editors. Principles and Practices of Pediatric Oncology. Philadelphia: Lippincott-Raven; 1997. pp.155-68.

31. Robison LL, Daigle A. Control selection using random digital dialing for cases of childhood cancer. Am J Epidemiol 1984;120:154-6.

32. Infante P, Epstein SS, Newton WA Jr. Blood dyscrasias and childhood tumors and exposure to chlordane and heptachlor. Scand J Work Environ Health 1978;4:137-50.

33. Kerr MA, Nasca PC, Mundt KA, Michalek AM, Baptiste MS, Mahoney MC. Parental occupational exposures and risk of neuroblastoma: a case-control study. Cancer Causes Control 2000;11:635-43.

34. Daniels JL, Olshan AF, Teschke K, Hertz-Picciotto L, Savitz DA, Blatt J, et al. Residential pesticide exposure and neuroblastoma. Epidemiology 2001;12(1):20-7.
35. Michelaelis J, Haaf HG, Zöllner J, Kaatsch P, Krummenauer F, Berthold F. Case control study of neuroblastoma in West-Germany after the Chernobyl accident. Klin Padiatr 1996;208(4):172-8.

36. Buckley JD, Meadows AT, Kadin ME, Le Beau MM, Siegel S, Robinson LL. Pesticide exposures in children with Non-Hodgkin's lymphoma. Cancer 2000;89(11):2315-21.

37. Beckwith JB, Kiviat NB, Bonadio JF. Nephrogenic rests, nephroblastomatosis, and the pathogenesis of Wilms' tumor. Pediatr Pathol 1990;10:1-36.

38. Breslow N, Olshan A, Berkwith JB, Green DM. Epidemiology of Wilms' tumor. Med Pediatr Oncol 1993;21:172-81.

39. Olshan A, Breslow NE, Falletta JM, Grufferman S, Pendergrass T, Robison LL, et al. Risk factors for Wilms' tumor: report from the National Wilms' Tumor Study. Cancer 1993;72:938-44.

40. Sharpe CR, Franco EL, de Camargo B, Lopes LR, Barreto JH, Johnsson RR, et al. Parental exposures to pesticides and the risk of Wilms' tumor in Brasil. Am J Epidemiol 1995;141:210-7.

41. Schwartzbaum JA, George SL, Pratt CB, Davis B. An exploratory study of environmental and medical factors potentially related to childhood cancer. Med Pediatr Oncol 1991;19:115-21.

42. Kantor AF, McCrea Curnen MG, Meigs JW, Flannery JT. Occupations of fathers of patients with Wilms' tumour. J Epidemiol Community Health 1979;33:253-6.

43. Wilkins JR, Sinks TH. Occupational exposures among fathers of children with Wilms' tumor. J Occup Med 1984;26:427-35.

44. Schüz J, Kaletsch U, Meinert R, Kaatsch P, Michaelis J. High birth weight and others risk factors for Wilms' tumour: results of a population-based case-control study. Eur J Pediatr 2001;160:333-8.

45. Pearce MS, Parker L. Paternal employment in agriculture and childhood kidney cancer. Pediatr Hematol Oncol 2000;17:223-30.

46. Chen Z, Stewart PA, Davies S, Giller R, Krailo M, Davis M, et al. Parental occupational exposure to pesticides and childhood germ-cell tumors. Am J Epidemiol 2005;162:858-67.

47. Fear NT, Roman E, Reeves G, Pannett B. Childhood cancer and paternal employment in agriculture: the role of pesticides. $\mathrm{Br} \mathrm{J}$ Cancer 1998;77(5):825-9.

48. Freedman DM, Stewart P, Kleinerman RA, Wacholder S, Hatch EE, Tarone RE, et al. Household solvent exposures and childhood acute lymphoblasitc leukemia. Am J Public Health 2001;91:564-7.

49. Gunier RB, Harnly ME, Reynolds P, Hertz A, Von Behren J. Agricultural pesticide use in California: pesticide prioritization, use densities, and population distributions for childhood cancer study. Environ Health Persp 2001;109(10):1071-8. 
50. Blair A, Zahm SH. Methodologic issues in exposure assessment for case-control studies of cancer and herbicides. Am J Ind Med 1990;18:285-93.

51. Garry F. Pesticides and children. Toxicol Applied Pharmacol 2004;198:152-63.
52. Bakketeing LS. Perinatal epidemiology - A Nordic challenge. Scand J Soc Med 1991;19:145-7.

53. Cnattingius S, Ericson A, Gunnarskog J, Källèn B. A quality study of a medical birth registry. Scand J Soc Med 1990;18:143-8. 